\title{
Impact of gene patents and licensing practices on access to genetic testing and carrier screening for Tay-Sachs and Canavan disease
}

\author{
Alessandra Colaianni, BA, Subhashini Chandrasekharan, PhD, and Robert Cook-Deegan, MD
}

\begin{abstract}
Genetic testing for Tay-Sachs and Canavan disease is particularly important for Ashkenazi Jews, because both conditions are more frequent in that population. This comparative case study was possible because of different patenting and licensing practices. The role of DNA testing differs between Tay-Sachs and Canavan diseases. The first-line screening test for Tay-Sachs remains an enzyme activity test rather than genotyping. Genotyping is used for preimplantation diagnosis and confirmatory testing. In contrast, DNA-based testing is the basis for Canavan screening and diagnosis. The HEXA gene for Tay-Sachs was cloned at the National Institutes of Health, and the gene was patented but has not been licensed. The ASPA gene for Canavan disease was cloned and patented by Miami Children's Hospital. Miami Children's Hospital did not inform family members and patient groups that had contributed to the gene discovery that it was applying for a patent, and pursued restrictive licensing practices when a patent issued in 1997. This led to intense controversy, litigation, and a sealed, nonpublic 2003 settlement that apparently allowed for nonexclusive licensing. A survey of laboratories revealed a possible price premium for ASPA testing, with per-unit costs higher than for other genetic tests in the Secretary's Advisory Committee on Genetics, Health, and Society case studies. The main conclusion from comparing genetic testing for Tay-Sachs and Canavan diseases, however, is that patenting and licensing conducted without communication with patients and advocates cause mistrust and can lead to controversy and litigation, a negative model to contrast with the positive model of patenting and licensing for genetic testing of cystic fibrosis. Genet Med 2010:12(4):S5-S14.
\end{abstract}

Key Words: patents, intellectual property, Tay-Sachs disease, Canavan disease, patient advocacy, genetic testing

T ay-Sachs and Canavan disease are both neurological conditions that predominantly but not exclusively affect the Ashkenazi Jewish population. Carrier screening and genetic diagnosis for Tay-Sachs are mainly through enzyme assay, with DNA-based testing for ambiguous cases or for diagnostic confirmation. DNA-based analysis is the mainstay for both screening and diagnostic confirmation of Canavan disease. Nonprofit research institutions obtained patents on both relevant genes, first the gene that when mutated causes Tay-Sachs (the HEXA gene encoding the enzyme hexosaminidase A) and later for Canavan disease (the $A S P A$ gene encoding aspartoacylase). The inventor for the HEXA patent worked at the National Institutes of Health (NIH), a government laboratory, and her Tay-Sachs

From the Center for Public Genomics, Center for Genome Ethics, Law \& Policy, Institute for Genome Sciences \& Policy, Duke University, Durham, North Carolina.

Robert Cook-Deegan, Center for Genome Ethics, Law \& Policy, Institute for Genome Sciences \& Policy, Duke University, Box 90141, Durham, NC 27708. E-mail: gelp@duke.edu.

Disclosure: The authors declare no conflict of interest. See Acknowledgments for details.

DOI: 10.1097/GIM.0b013e3181d5a669 patent was never licensed. That discovery is, therefore, effectively in the public domain. The patents relevant to Canavan disease, in contrast, were licensed by Miami Children's Hospital. The patents were eventually nonexclusively licensed at least 20 times. Patenting and licensing were initially highly controversial and led to litigation. Because the two diseases are pathologically similar and affect the same population, this difference in licensing history created a natural experiment to assess the impact of licensing practices on patients' and physicians' clinical access to genetic tests.

\section{BACKGROUND}

Tay-Sachs disease (TSD) is a progressive disease that destroys brain function. TSD is caused by inheriting two mutated copies of the HEXA gene (one from each parent), which produces the hexosaminidase A subunit of an enzyme-protein complex. In an unaffected individual, the enzyme is part of a pathway that degrades Gm2 gangliosides, complex proteincarbohydrate molecules. In an individual affected by TSD, the absence or reduced activity of the enzyme causes the Gm2 gangliosides to build up in the brain - the metabolic pathway is blocked. This causes progressive destruction of the central nervous system. There are three types of TSD, differentiated by age of onset: acute infantile, juvenile, and late-onset. Infantile onset is the most common. In the classic progression of acute infantile TSD, the infant gets progressively weaker and loses motor skills between the ages of 6 months and 3 years. The infant has progressively diminished attentiveness and an exaggerated startle response. As TSD continues to destroy the brain, the infant suffers seizures, blindness, and eventually death, which usually occurs before 4 years of age. Disease progression is painful for its victim and agonizing for parents and family. There is no cure for TSD, and treatment is limited to supportive care. ${ }^{1}$ Clinical details are summarized in Table 1.

Canavan disease also causes progressive deterioration of the brain. It is caused by inheriting two mutated copies of the ASPA gene, which encodes the aspartoacylase enzyme. In a normal individual, aspartoacylase breaks down $N$-acetylaspartic acid. In Canavan disease, the lack of aspartoacylase leads to a buildup of $\mathrm{N}$-acetylaspartic acid in the brain, which causes demyelination and degeneration. ${ }^{2}$ Symptoms of Canavan disease are macrocephaly (larger than normal head size), lack of head control, developmental delays by the age of 3-5 months, and loss of muscle control. As the brain continues to deteriorate, the affected child suffers from muscle spasms and seizures. Individuals with Canavan disease are expected to live into their teens. ${ }^{3}$ Similar to TSD, there is no cure for Canavan disease, and treatment is limited to supportive care. Clinical details are summarized in Table 1.

Because there is no official disease registry for either TSD or Canavan disease, it is difficult to estimate how many children in the United States are affected per year by each disease. However, Kim Crawford, the Director of Member Services at the National Tay-Sachs and Allied Diseases Association (NTSAD) 
Table 1 Summary of clinical details

\begin{tabular}{|c|c|c|}
\hline & Tay-Sachs disease & Canavan disease \\
\hline Mode of inheritance & $\begin{array}{l}\text { Autosomal recessive (each offspring has a one } \\
\text { in four chance of receiving the mutated } \\
\text { gene from both parents and thus being } \\
\text { affected by the condition) })^{1}\end{array}$ & Autosomal recessive $^{3}$ \\
\hline Cause & $\begin{array}{l}\text { Hexosaminidase A deficiency, leading to } \\
\text { buildup of Gm2 gangliosides in neuronal } \\
\text { cells }^{1}\end{array}$ & $\begin{array}{l}\text { Aspartoacylase deficiency leading to build up of } N \text {-acetylaspartic } \\
\text { acid, leading to demyelination and spongy degeneration of the } \\
\text { brain }^{16}\end{array}$ \\
\hline Symptoms & $\begin{array}{l}\text { Weakness, loss of motor skills, decreased } \\
\text { attentiveness, increased startle response, } \\
\text { death usually before the age of } 4 \text { years }{ }^{1}\end{array}$ & $\begin{array}{l}\text { Macrocephaly (large head), lack of head control, hypotonia (lack } \\
\text { of muscle tone), seizures, spasticity, failure to achieve } \\
\text { independent sitting, ambulation, or speech, death usually } \\
\text { before teenage years }{ }^{3}\end{array}$ \\
\hline Treatment & Supportive & Supportive \\
\hline Carrier rate (Ashkenazim) ${ }^{4}$ & $1: 31$ & $1: 41$ \\
\hline $\begin{array}{l}\text { Natural incidence } \\
\text { (based on a carrier rate } \\
\text { of } 1: 30 \text { and } 1: 40^{33} \text { ) }\end{array}$ & $1: 3000$ & $1: 6400$ \\
\hline
\end{tabular}

estimated, based on the Foundation's best data, that there are 12-15 new infantile diagnoses of TSD a year, and $\sim 50$ children currently living in the United States with Tay-Sachs. (Ms. Crawford's estimates also include cases of Sandhoff disease, a clinically similar disorder.) NTSAD is the primary support community for families affected by Tay-Sachs, so their estimates are likely as accurate as can be found. Estimates for Canavan disease are more difficult to find, because data for the Canavan community are divided among three major centers: NTSAD, the United Leukodystrophy Foundation, and the Canavan Foundation. However, Drs. Paola Leone (University of Medicine \& Dentistry of New Jersey) and Edwin Kolodny (New York University Medical Center) estimate that they see an average of 15-30 new cases a year (E. Kolodny, Department of Neurology, New York University; and P. Leone, Department of Cell Biology, University of Medicine and Dentistry of New Jersey, personal communications, 2007). Lois Neufeld, past president of the Canavan Foundation, estimated in a phone interview that there are at least 500 children in the United States living with Canavan disease (L. Neufeld, former President of Canavan Foundation, personal communication, 2007).

\section{GENETIC TESTS FOR TAY-SACHS AND CANAVAN DISEASE, AND ASSOCIATED PATENTS}

For a summary, see the timeline in the appendix at the end of the article.

\section{Tay-Sachs}

There are two basic types of tests used to screen people for TSD: one is an enzyme assay, and the other is a DNA-based test. The enzyme test, which was the basis of many carrier screening campaigns in the United States, is still widely used for carrier screening and diagnosis. The DNA-based test can be used to confirm an inconclusive enzyme test, to identify the specific mutation in an individual, to evaluate an individual for a pseudodeficiency allele (a sequence variant, in this case one or two copies of the R247 or R249 W alleles, that does not alter protein function sufficiently to cause disease and thus means that a person is not a carrier for TSD) ${ }^{4}$ for carrier testing, and for prenatal testing, including preimplantation genetic diagnosis (PGD). ${ }^{4}$ Some members of the Ashkenazi population use the HEXA DNA test for carrier screening, before an enzyme test. ${ }^{1}$ Because the enzyme test will detect all those affected while the DNA test will detect only those affected by known mutations, some carriers may not be identified by the DNA test alone. Monaghan et al. ${ }^{4}$ put the sensitivity of the enzyme test at $97-98 \%$ and the DNA test at $95 \%$.

\section{Enzyme test}

Drs. John O'Brien and Shintaro Okada developed the first enzyme test in the early 1970s. ${ }^{5}$ Dr. Michael Kaback modified the O'Brien enzyme test and used it to spearhead a Tay-Sachs carrier screening campaign in Washington and Baltimore in the 1970 s. ${ }^{6}$ As a result of the Baltimore/Washington screening campaign, $>100$ cities began their own Tay-Sachs screening campaigns, which resulted in a $>90 \%$ reduction in the disease incidence. ${ }^{7}$ The Dor Yeshorim screening program for members of the orthodox Jewish community, led by Rabbi Josef Ekstein, also used this enzymatic test for its carrier screening campaigns. ${ }^{8}$ The enzyme test detects enzyme function: carriers (people with one normal and one abnormal allele) have 50\% normal enzyme function, and those with the disease have $<10 \%$ enzymatic function. ${ }^{5}$ The enzyme test detects $\sim 97-98 \%$ of carriers, no matter their specific mutation. ${ }^{4}$ Versions of this enzyme test are still widely used today. According to Dr. Kaback, there was never any effort to patent the original Tay-Sachs enzyme test (M. Kaback, Professor of Pediatrics, University of California San Diego, personal communication, 2007).

\section{DNA test}

Dr. Rachel Myerowitz was working as a postdoctoral fellow at the NIH under Dr. Elizabeth F. Neufeld when she decided to clone the defective Tay-Sachs gene. She had previously done her biochemistry thesis at the University of Michigan on GM1 gangliosidosis, another rare lysosomal disorder. When she began in Dr. Neufeld's laboratory, she worked on Hurler syndrome, another lysosomal disorder caused by defective iduronidase enzyme, ${ }^{9}$ and decided that she wanted to clone the iduronidase gene. However, material from Tay-Sachs patients was easier to obtain, so she switched to cloning the genes for hexosaminidase (R. Myerowitz, Department of Biology, St. Mary's College of Maryland, personal 
communication, 2007). Dr. Myerowitz isolated a cDNA clone of the HEXA gene in 1983 and published these results in $1984 .{ }^{10}$ In 1984, Dr. Neufeld, moved from NIH to University of California, Los Angeles. Dr. Myerowitz remained at the NIH and looked for mutations in the HEXA gene that were present in the Ashkenazi Jewish population.

Patenting the gene had never occurred to her, but, as she put it, ". . . in the late 1980 s, NIH was very interested in patenting stuff. They would come around to your laboratory and say, 'Do you have anything that you think is patentable?"' (R. Myerowitz, personal communication, 2007). Myerowitz was approached by a lawyer from NIH who advised her to file a patent application. NIH filed a patent application in 1986 and was granted two patents: the first, US 5,217,865 "Screening for Tay-Sachs disease with cloned DNA for beta-hexosaminidase," issued in 1993, which covers diagnostic testing; and the second, US 5,475,095 "Nucleic acid compositions for the alpha chain of beta-hexosaminidase," issued in 1995, which covers the HEXA gene itself. US patent 5,217,865 has a filing date of October 31, 1988, and US 5,475,095 has a filing date of December 7, 1993; however, both stemmed from one original application 889,502, filed July 5, 1986. During the patent prosecution process, the original application's claims were split into two separate patents.

Myerowitz left the NIH in 1993 for a position at St. Mary's College of Maryland. In 2000, she contacted the NIH legal department to ask about developments with the patents. The legal department told her that although they knew the DNA test based on the patents was widely used, they had never drafted a license because going after infringers was "more trouble than it [was] worth" (R. Myerowitz, personal communication, 2007). Thus, although the Tay-Sachs gene was patented, the patents were never licensed and never enforced.

\section{Canavan disease}

The gene for Canavan disease, called $A S P A$, was discovered and patented by Dr. Reuben Matalon and coinventors. Dr. Matalon is now at the University of Texas Medical Branch Center for Metabolic Diseases; at the time the gene was discovered and patented, Matalon was affiliated with Miami Children's Hospital (MCH). Matalon had been recruited in May 1987 to search for the cause of Canavan disease, while he was a professor at the University of Illinois at Chicago, by Daniel and Deborah Greenberg, a Chicago-based family that had two children, Jonathan and Amy, born with Canavan disease. ${ }^{11}$ By 1988, Matalon had discovered and published an article in the American Journal of Medical Genetics about the aspartoacylase deficiency that causes Canavan disease. ${ }^{12}$ In 1989, Matalon took a position as director of research at the $\mathrm{MCH} .{ }^{11}$

In 1990, Matalon published an article in the Journal of Inherited Metabolic Diseases detailing a prenatal enzymatic screening test that could diagnose Canavan disease using amniocytes (cells taken from the amniotic fluid of a gestating pregnancy) or chorionic villus sampling (CVS; cells taken from the placenta). ${ }^{13}$ However, the enzymatic testing method proved to be unreliable: it resulted in the births of four babies with Canavan disease, who had been prenatally screened and pronounced free of the disease. ${ }^{14}$ At least two lawsuits against $\mathrm{MCH}$ resulted, which were settled out of court. ${ }^{11}$ It was later determined that Matalon's enzymatic test did not work because the amniocytes and CVS did not have enough enzymatic activity to provide an accurate screen. ${ }^{15}$ Matalon's enzymatic test also could not distinguish adult Canavan carriers from noncarriers. ${ }^{16}$ Matalon did not receive a patent on this test. In 1993, Bennett et al. ${ }^{17}$ published results that suggested that prenatal diagnosis using an enzyme assay of amniotic fluid (rather than amniocytes or CVS) provided more reliable results. However, complications with the amniotic fluid assay were reported: it was only reliable at the extremes, and mid-range levels of enzyme activity were inconclusive. ${ }^{18}$ According to the NTSAD, only two or three laboratories in the United States offer that test. ${ }^{19}$ One study recommended that DNA sequencing should accompany amniotic fluid screening wherever possible. ${ }^{18}$ The Bennett et al. test was not patented (M.J. Bennett, Professor of Pathology and Laboratory Medicine, University of Pennsylvania, personal communication, 2008). Unlike TSD, then, the only way to provide carrier screening for Canavan disease was through DNA-based testing, and DNAbased prenatal diagnosis would be an easier and more reliable method than amniotic fluid analysis.

On October 1, 1993, Matalon and his researchers published exciting results in Nature Genetics: they had isolated and sequenced the aspartoacylase gene and found a common mutation that causes Canavan disease. ${ }^{20}$ This made a DNA-based Canavan test possible, and the Ashkenazi population leapt into action. Rabbi Josef Ekstein, who had spearheaded the Dor Yeshorim Tay-Sachs screening campaign in the 1980s, screened $\sim 13,000$ people that year for Canavan disease, and in 1996, the Canavan Foundation offered free testing at New York's Mount Sinai Hospital. ${ }^{11}$

Matalon filed a patent application on September 29, 1993, and was granted two US patents, US 5,679,635 in October 1997, and US 7,217,547 in May 2007, both entitled "Aspartoacylase gene, protein, and methods of screening for mutations associated with Canavan disease." US 5,679,635 has a filing date of September 9, 1994, and US 7,217,547 has a filing date of October 1, 2001. However, both patents' Parent Case Text show that they stemmed from the same application 08/128,020, filed September 29, 1993. The patent granted in 1997 covered the DNA sequence of the gene, mutated sequences associated with Canavan disease, use of the sequence in DNA testing, and test kits for Canavan disease. The patent granted in 2007 claimed mutated versions of the aspartoacylase protein. The patents were assigned to the Miami Children's Hospital Research Institute, Inc.

After the first patent was granted, MCH's chief financial officer, David Carroll, sent letters to laboratories and hospitals, advising them that $\mathrm{MCH}$ had received the patent, and that those doing Canavan tests would have to take out a license or risk an infringement lawsuit. One such letter, received by Debra Leonard in 1999, stated: "We intend to enforce vigorously our intellectual property rights relating to carrier, pregnancy, and patient DNA tests for Canavan Disease mutations." 21 The letter described a $\$ 12.50$ royalty for each test. The price was marked down from a reported $\$ 25 .{ }^{11}$ According to Joshua Greenberg, son of Daniel and Debbie Greenberg, $\mathrm{MCH}$ had originally set the price at $\$ 50$. The letter also set volume limitations of 100 individual tests per academic laboratory per year (M. Watson, Executive Director, American College of Medical Genetics [ACMG], personal communication, 2007).

The enforcement of the MCH patent (US 5,679,635) angered many in the Canavan community, including Rabbi Josef Ekstein, members of the Canavan Foundation, and the Greenberg family. In response, the Canavan Disease Screening Consortium was formed. The Consortium consisted of the Canavan Foundation, the NTSAD, the National Foundation for Jewish Genetic Diseases, and the Canavan Research Fund. On January 20, 2000, the Canavan Disease Screening Consortium, including Judith Tsipis (NTSAD), Michael Watson (American College of Medical Genetics), Jon Merz (University of Pennsylvania), Orren Alperstein Gelblum, Rosalind Poss Rosen (both of the Canavan Foundation), and Daniel Greenberg (NTSAD) made a 
presentation to officials from $\mathrm{MCH}$, explaining that they believed the MCH's licensing policies were too restrictive. They wanted the Canavan patent to be dedicated to the public good, as the University of Michigan's patent for the Cystic Fibrosis gene had been. If the patent could not be dedicated to the public good, they requested four actions from $\mathrm{MCH}$ :

1. Remove the volume cap on testing;

2. Charge a royalty not $>1-5 \%$ of the test price;

3. Develop an educational outreach program to promote carrier screening; and

4. Set up a fund to assist people unable to pay for screening or prenatal diagnosis (M. Watson, personal communication, 2007).

According to Dr. Michael Watson, Executive Director of the ACMG, who was present at the meetings, the representatives of $\mathrm{MCH}$ offered an undisclosed sum of money to be used for the proposed educational outreach program but did not agree to the Consortium's other requests (M. Watson, personal communication, 2007). An article by Jon Merz, who was also present at the meetings, says the offered sum was $\$ 20,000$ per year, with the further condition that the Consortium members not publicly criticize the $\mathrm{MCH} .{ }^{22}$ The Consortium welcomed the financial help but did not agree to the gag order. ${ }^{22}$

The $\mathrm{MCH}$ marketing plan had two phases: first, $\mathrm{MCH}$ would offer nonexclusive licenses to a limited number of academic laboratories, allowing them to perform a limited number of tests per year. Then, MCH would identify a "market leader"- a single, high-volume licensee such as Quest or LabCorp - and grant them an exclusive license on the remainder of the testing volume $(\mathrm{p}$ 103). ${ }^{22} \mathrm{MCH}$ originally planned to offer seven unrestricted licenses to the Canavan patents (M. Watson, personal communication, 2007).

The effort to find a single large-volume licensee failed, and in April 2000, MCH revised its licensing plan. ${ }^{22}$ In the meantime, Dr. Debra Leonard had been performing Canavan disease testing in her University of Pennsylvania laboratory since before the patent issued. On advice from counsel, she refused to sign the $\mathrm{MCH}$ 's license agreement with volume limitations and the $\$ 12.50$ royalty. However, $\mathrm{MCH}$ was owed back royalties from the tests that Leonard had previously performed without a license, and Marc Golden, MCH's advisor and consultant, drafted a settlement agreement that prohibited any University of Pennsylvania physician from "perform[ing] or hav[ing] other(s) perform, any Canavan Tests . . . without first obtaining a license."22 This would not only prevent Canavan testing at the University of Pennsylvania but would also prevent University of Pennsylvania physicians from collecting samples and sending them out to licensed laboratories, until the University of Pennsylvania itself obtained a license, which would be at the discretion of $\mathrm{MCH}$. After negotiations, the University agreed to pay $\mathrm{MCH}$ past royalties and not infringe the patent in the future. ${ }^{22}$

In the meantime, tensions rose between the $\mathrm{MCH}$, on one hand, and Leonard and the Consortium, on the other. Both Leonard and members of the Consortium tried to learn the names of the dozen or so laboratories that had taken licenses - Leonard, so that she could send samples to licensed laboratories, and the Consortium so that they could direct the community at risk to laboratories at which they could legally be tested. MCH stated that it would release the names of four laboratories, out of $\sim 12$ that had obtained licenses, to Dr. Leonard, and did not provide any information about licensed services to the Consortium. ${ }^{22}$

In October 2000, the Greenberg v. Miami Children's Hospital lawsuit was filed. $\mathrm{MCH}$ had alienated the groups that directly contributed clinical data and samples to help discover the gene associated with Canavan disease, and the constituencies most likely to use genetic testing. That is, the licensing scheme offended important and influential users of the Canavan genetic test. Daniel Greenberg, along with the Canavan Foundation, Dor Yeshorim, NTSAD, and three other plaintiffs who had children afflicted with Canavan disease, sued $\mathrm{MCH}$, the Miami Children's Hospital Research Institute and Reuben Matalon. The plaintiffs filed a six-count complaint, alleging a lack of informed consent, breach of fiduciary duty, unjust enrichment, fraudulent concealment, conversion, and misappropriation of trade secrets. ${ }^{23}$ On August 3, 2003, the case settled confidentially outof-court, and a gag order prevents us from knowing the exact terms of the settlement. A press release from the Canavan Foundation characterized the agreement as follows:

Canavan Foundation, National Tay-Sachs \& Allied Diseases Association, Daniel Greenberg and David Green have agreed not to further challenge Miami Children's Hospital's ownership and licensing of the Canavan gene patent. Miami Children's Hospital will continue to license and collect royalty fees for clinical testing for the Canavan gene mutation. The Agreement also allows license-free use of the Canavan gene in research to cure Canavan disease, including in gene therapy research, genetic testing in pure research, and in mice used to research Canavan disease. ${ }^{24}$

A phone survey conducted in 2001 by Cho et al., ${ }^{25}$ showed that as of September 2001, four Canavan test providers listed on Genetests.org had stopped performing that test, citing the $\mathrm{MCH}$ patent as the reason for stopping. The study of Cho et al. did not contain information on exactly how many laboratories were performing the Canavan test before 2001, so it is impossible to say what fraction of laboratories stopped performing the Canavan test due to patent enforcement.

\section{Testing facilities and prices}

A 2003 newspaper article reported that $\mathrm{MCH}$ had licensed the patent to 15 laboratories. ${ }^{11}$ In June 2007, Genetests.org listed 37 facilities that provide Canavan disease testing, diagnosis, and/or carrier screening. Of these 37 facilities, 23 are listed as providing mutation analysis, full sequencing, carrier testing, and/or prenatal diagnosis. These are all DNA-based tests, so those laboratories have most likely taken a license with $\mathrm{MCH}$. Fourteen laboratories are listed as providing analyte testing only, which does not include DNA analysis and would not require a license. In June 2007, Genetests.org also listed 34 laboratories that performed Tay-Sachs testing. Of these, 26 laboratories were listed as performing both Tay-Sachs and Canavan testing.

A telephone survey of all 45 laboratories offering Canavan testing, Tay-Sachs testing, or both was performed between June and August 2007. Of the 45 laboratories, 6 did not respond to repeated telephone calls, 2 stated that they no longer offered the Tay-Sachs test, and 5 no longer offered the Canavan test. In addition, 5 laboratories stated that they only provided the tests as part of a panel including other genetic tests, and these laboratories were excluded. Laboratory personnel, usually receptionists or billing staff, were asked for the list price of the test in question. When the tests were only available as part of a panel, we did not report the price of the test. Personnel were not asked whether they had a license for the $\mathrm{MCH}$ patents, as a negative answer to such a question could have posed a liability to the laboratory. Personnel were not asked whether they had 
taken a license of the Tay-Sachs patent, as the authors knew from the NIH Office of Technology Transfer staff that it was never licensed.

In Tables 2-5, the tests are divided into several different categories, based on test category information available from Genetests.org, on the website of the testing service, or descriptions of the type of test performed. Tests were divided into categories of Full Sequence Analysis, Targeted Mutation Analysis, and Enzyme Assay/Analyte. Price per Amplicon for Full Sequence Analysis was calculated by dividing the price of the test by the number of amplicons the test sequences; for TaySachs, full sequencing entails 14 amplicons (for the 14 exons in the gene), and for Canavan disease, full sequencing entails 6 amplicons (for the 6 exons in the gene).

The data show that, despite the differences in intellectual property, the only significant pricing difference between Canavan and Tay-Sachs laboratory tests occurs in the average price per amplicon. Average test prices of the tests for Tay-Sachs and Canavan Disease were usually $<\$ 10$ apart. The exception is the Ambry full sequence analysis for Tay-Sachs, which is $\$ 800$ more than the comparable Canavan test. It is unclear why the Ambry Tay-Sachs test would be so much more expensive than the Ambry Canavan test. One possible reason is that the hexosaminidase gene is longer than the aspartoacylase gene: the ASPA gene is $29 \mathrm{~kb}$ and the HEXA gene is $35 \mathrm{~kb} \cdot{ }^{4}$ Based on the Ambry prices and the length of the respective genes, the price per base pair for the Ambry Canavan test is \$0.031; the price per base pair for the Ambry Tay-Sachs test is $\$ 0.048$. The average price per amplicon for Tay-Sachs, however, is $\$ 111.50$, whereas the price per amplicon for Canavan disease is \$199.58: a significant difference that could reflect a patent premium.

There are several confounding factors that may affect these data. First, the number of laboratories offering each test may be inaccurate, because some "laboratories" are only sample collection points, which then send the samples they collect to other laboratories that perform the test. This would affect both the number of laboratories offering the test, and the number of laboratories that have a sublicense of the $\mathrm{MCH}$ patents. Also, at least in the case of TSD, many schools, universities, and Jewish organizations (such as the Dor Yeshorim) offer free carrier screening throughout the year, which could significantly increase access but does not appear on genetests.org. For example, a branch of NTSAD in the Delaware Valley offered six free Canavan and Tay-Sachs screening dates during the months of May and early June in 2007, and published a list

Table 2 Full sequence analysis

\begin{tabular}{lcc}
\hline & \multicolumn{2}{c}{ Test price $^{a}$} \\
\cline { 2 - 3 } Laboratory & $\begin{array}{c}\text { Tay-Sachs } \\
\text { disease }\end{array}$ & $\begin{array}{c}\text { Canavan } \\
\text { disease }\end{array}$ \\
\hline Ambry Genetics & $\$ 1,695$ & $\$ 895$ \\
$\begin{array}{l}\text { Emory University Department of Human } \\
\text { Genetics }\end{array}$ & $\$ 1,488^{42}$ & Not offered \\
$\begin{array}{l}\text { New York University } \\
\begin{array}{l}\text { School of Medicine } \\
\text { Neurogenetics Laboratory }\end{array}\end{array}$ & $\$ 1,500$ & $\$ 1,500$ \\
$\begin{array}{l}\text { Average test price } \\
\begin{array}{l}a \\
\text { Unless otherwise noted, prices come from personal communications with the } \\
\text { relevant laboratories. }\end{array}\end{array}$ \\
\hline
\end{tabular}

Table 3 Full sequence analysis, price per amplicon

\begin{tabular}{|c|c|c|}
\hline \multirow[b]{2}{*}{ Laboratory } & \multicolumn{2}{|c|}{ Test price } \\
\hline & Tay-Sachs disease $\mathrm{e}^{a, b}$ & Canavan disease ${ }^{a, c}$ \\
\hline Ambry Genetics & $\$ 121.07$ & $\$ 149.17$ \\
\hline $\begin{array}{l}\text { Emory University } \\
\text { Department of Human } \\
\text { Genetics }\end{array}$ & $\$ 106.29^{42}$ & Not offered \\
\hline $\begin{array}{l}\text { New York University } \\
\text { School of Medicine } \\
\text { Neurogenetics Laboratory }\end{array}$ & $\$ 107.14$ & $\$ 250$ \\
\hline Average test price & $\$ 111.50$ & $\$ 199.58$ \\
\hline \multicolumn{3}{|c|}{$\begin{array}{l}{ }^{a} \text { Unless otherwise noted, prices come from personal communications with the } \\
\text { relevant laboratories. } \\
{ }^{b} \text { Fourteen amplicons for Tay-Sachs disease testing. }\end{array}$} \\
\hline
\end{tabular}

Table 4 Targeted mutation analysis

\begin{tabular}{|c|c|c|}
\hline \multirow[b]{2}{*}{ Laboratory } & \multicolumn{2}{|c|}{ Test price ${ }^{a}$} \\
\hline & $\begin{array}{l}\text { Tay-Sachs } \\
\text { disease }\end{array}$ & $\begin{array}{l}\text { Canavan } \\
\text { disease }\end{array}$ \\
\hline ARUP Laboratories & $\$ 300$ & $\$ 300$ \\
\hline Baylor College of Medicine & Not offered & $\$ 125$ \\
\hline $\begin{array}{l}\text { Boston University Medical } \\
\text { Center }\end{array}$ & $\$ 135$ & $\$ 195$ \\
\hline $\begin{array}{l}\text { Children's Hospital and } \\
\text { Regional Medical Center }\end{array}$ & Not offered & $\$ 428.40$ \\
\hline Genzyme Genetics & $\$ 284$ & $\$ 284$ \\
\hline Kimball Genetics & $\$ 315$ & Not offered \\
\hline LabCorp & $\$ 334$ & $\$ 345$ \\
\hline $\begin{array}{l}\text { Mayo Clinic Biochemical } \\
\text { Genetics Laboratory }\end{array}$ & $\$ 315$ & $\$ 366.80$ \\
\hline New Jersey Medical School & $\$ 100$ & $\$ 100$ \\
\hline $\begin{array}{l}\text { New York University School of } \\
\text { Medicine Medical Genetics Lab }\end{array}$ & $\$ 252$ & $\$ 128$ \\
\hline $\begin{array}{l}\text { New York University School of } \\
\text { Medicine Neurogenetics } \\
\text { Laboratory }\end{array}$ & $\$ 600$ & $\$ 600$ \\
\hline ProGene, Inc. & $\$ 175$ & $\$ 175$ \\
\hline Quest Diagnostics, Inc. & $\$ 252$ & $\$ 355$ \\
\hline Specialty Laboratories & $\$ 440$ & $\$ 440$ \\
\hline $\begin{array}{l}\text { Wayne State University/Detroit } \\
\text { Medical Center University } \\
\text { Laboratories }\end{array}$ & $\begin{array}{l}\text { Only offered as } \\
\text { part of panel }\end{array}$ & $\$ 325$ \\
\hline
\end{tabular}

Average price of test:

$\$ 291.84$

$\$ 297.66$ relevant laboratories.

of nine hospitals offering free screening throughout the month of May 2007.26 Other examples of universities offering free Tay-Sachs screening included the University of Wisconsin-Madison (2003 and 2004), ${ }^{27}$ Santa Monica Col- 
Table 5 Enzyme assay (Tay-Sachs)/analyte test (Canavan)

\begin{tabular}{|c|c|c|}
\hline \multirow[b]{2}{*}{ Laboratory } & \multicolumn{2}{|c|}{ Test price $^{a}$} \\
\hline & Tay-Sachs disease ${ }^{a}$ & Canavan disease $^{a, b}$ \\
\hline Baylor College of Medicine & $\$ 128$ & Not offered \\
\hline \multirow[t]{2}{*}{ Children's National Medical Center } & $\$ 119$ (serum) & Not offered \\
\hline & \multicolumn{2}{|l|}{$\$ 172$ (white blood cells) } \\
\hline Duke University & Not offered & $\$ 260$ \\
\hline Emory University Department of Human Genetics ${ }^{c}$ & $\$ 250^{43}$ & Not offered \\
\hline Emory University Department of Human Genetics ${ }^{d}$ & $\$ 525^{44}$ & Not offered \\
\hline Genzyme Genetics & $\$ 134$ & Not offered \\
\hline Greenwood Genetics Center & Not offered & $\$ 200$ (analyte) \\
\hline Kennedy Krieger Institute & Not offered & $\$ 150$ (analyte) $^{45}$ \\
\hline Kimball Genetics, Inc. & $\$ 160$ & Not offered \\
\hline \multirow[t]{2}{*}{ LabCorp } & \$347 (leukocyte) & \multirow[t]{2}{*}{ Not offered } \\
\hline & $\$ 175$ (serum) & \\
\hline \multirow[t]{2}{*}{ Mayo Clinic Biochemical Genetics Laboratory } & $\$ 188.30($ serum $)$ & \multirow[t]{2}{*}{ Not offered } \\
\hline & $\$ 277.70$ (white blood cells) & \\
\hline \multirow{2}{*}{$\begin{array}{l}\text { New York State Institute of Basic Research in Developmental } \\
\text { Disabilities }\end{array}$} & $\$ 280$ (leukocytes) & \multirow[t]{2}{*}{$\$ 168$ (organic acids) } \\
\hline & $\$ 260$ (plasma) & \\
\hline \multirow[t]{2}{*}{ Oregon Health and Science University } & $\$ 119.44$ & \multirow[t]{2}{*}{ Not offered } \\
\hline & $\$ 223.42$ (rush) & \\
\hline $\begin{array}{l}\text { University of Alabama at Birmingham Metabolic Disease } \\
\text { Laboratory }\end{array}$ & $\$ 300$ & Not offered \\
\hline UCSD Molecular Genetics Laboratory & $\$ 116$ & Not offered \\
\hline \multirow{2}{*}{$\begin{array}{l}\text { University of Maryland Pediatric Biochemical Genetics } \\
\text { Laboratory }\end{array}$} & $\$ 90$ (serum) & \multirow[t]{2}{*}{ Not offered } \\
\hline & \$155 (leukocytes) & \\
\hline Wayne State University/Detroit Medical Center & $\$ 63$ & Not offered \\
\hline Average test price & $\$ 204$ & $\$ 195$ \\
\hline
\end{tabular}

lege (2003), ${ }^{28}$ University of California at Davis (2005), ${ }^{29}$ and San Jose University (2001). ${ }^{30}$

One other confounding factor is the pricing of the tests themselves. Laboratory prices may reflect a change in licensing policy from MCH's original \$12.50 royalty; however, because the Greenberg v $\mathrm{MCH}$ settlement was sealed, any agreed royalty rate may never be publicly available. Overhead costs may also contribute to pricing differences.

\section{SCREENING FOR TAY-SACHS AND CANAVAN DISEASE}

In 1995, the American College of Obstetricians and Gynecologists (ACOG) published a committee opinion recommending carrier screening for TSD before pregnancy if both parents are of Ashkenazi Jewish, French-Canadian, or
Cajun descent. ${ }^{31}$ That opinion was renewed and republished in 2005: if both parents were carriers of a mutated HEXA gene, genetic counseling and prenatal diagnosis should be offered.

In 1998, ACOG issued a similar committee opinion for Canavan disease, recommending carrier screening for Canavan disease if both parents were of Ashkenazi Jewish descent. ${ }^{16}$ If both parents were carriers of an $A S P A$ functional mutation, prenatal diagnosis would use DNA-based $A S P A$ testing.

Also in 1998, the ACMG issued a position statement that people of Ashkenazi Jewish descent should be offered screening for Canavan disease before becoming pregnant; ACMG also suggested that screening for Canavan disease could be combined with screening for Tay-Sachs, since both disorders were common among Ashkenazi Jewish people. ${ }^{32}$ 
In 2004, the ACOG issued another committee opinion reiterating recommendations that people of Ashkenazi Jewish descent should be offered carrier screening for Tay-Sachs and Canavan disease, in addition to seven other diseases that are common to that group. ${ }^{33}$

These ACOG and ACMG recommendations help set the standard of care for screening for Tay-Sachs and Canavan disease in the United States.

\section{CLINICAL UTILITY OF GENETIC TESTING FOR TAY-SACHS AND CANAVAN DISEASE}

\section{Tay-Sachs}

The Tay-Sachs Hexosaminidase A enzyme activity assay is very sensitive, with a $97-98 \%$ detection rate. ${ }^{4}$ DNA testing for three common mutations detects $>98 \%$ of Jewish carriers and $93 \%$ of Jewish carriers are identified by the enzyme assay. ${ }^{4}$ One study identified DNA-based testing as the preferred carrier screening method in individuals of full Ashkenazi Jewish descent. ${ }^{34}$ DNA-based testing is also the only method to do PGD, to confirm which specific mutation an individual has, or to rule out the possibility of pseudodeficiency alleles. In general, the enzyme test is inexpensive, accurate, and easy to do. It is also the best method to detect carrier status in individuals who are not of Ashkenazi Jewish descent (because any mutations might not be known DNA changes detected in current DNA-based tests).

\section{Canavan disease}

DNA testing for Canavan disease is based on two common mutations that account for $97-98 \%$ of Ashkenazi Jewish carriers. ${ }^{4}$ Another mutation accounts for $\sim 1 \%$ of the Ashkenazi Jewish population and about $50 \%$ of the non-Ashkenazi Jewish population. ${ }^{4}$ DNA testing for Canavan Disease is the only way to detect carrier status, because enzymatic screens often fail to distinguish carriers from noncarriers. ${ }^{16}$ In addition, prenatal testing using amniotic fluid (not CVS or amniotic cells, as previously discussed) is available but not widespread. ${ }^{4}$

\section{COST-EFFECTIVENESS OF SCREENING FOR TAY- SACHS AND CANAVAN DISEASE}

We have been unable to find any cost-effectiveness or costbenefit analysis of genetic screening for Canavan Disease. We have also been unable to find any cost-effectiveness or costbenefit analysis of DNA-based testing for TSD. There are a few studies that do address the cost-benefit or cost-effectiveness of the Tay-Sachs enzyme test; however, they do not address the economics of the DNA-based test. This may be because screening for such devastating, incurable diseases as Tay-Sachs and Canavan is considered to be worth whatever the screening program costs. A quote from the NTSAD, Inc., illustrates this:

It is important to note that while the [insurance] appeal process and potential out-of-pocket cost of genetic testing may seem daunting it is a drop in the bucket compared to caring for a child affected by Tay-Sachs, Canavan or another allied disease. ${ }^{35}$

\section{LESSONS LEARNED}

\section{Research}

It is clear that the Tay-Sachs gene patent did not stifle research as it was never enforced. The Canavan patent may or may not have stifled basic research until 2003, when the terms of settling Greenberg v Miami Children's Hospital were reached. Clinical research laboratories and commercial laboratories received cease-and-desist letters from MCH in 1998, which could have stopped them from sequencing the $A S P A$ gene and thus have stifled basic research and some clinical research. ${ }^{36}$ As discussed previously, one of the terms of the agreement allowed "license-free use of the Canavan gene in research to cure Canavan disease, including in gene therapy research, genetic testing in pure research, and in mice used to research Canavan disease." 24 Thus, although the Canavan patent could in theory have impeded research until 2003, it does not now do so.

\section{Development and commercialization}

The Tay-Sachs patent neither helped nor hindered commercialization of the Tay-Sachs DNA test. One company approached Dr. Rachel Myerowitz before the patent issued to ask whether the gene would be patented. According to her, the company did not want to develop a test kit unless the gene was patented. Once the patent issued, however, NIH decided it would be too much trouble to enforce the patent, so it was never licensed. The presence of a reliable enzyme test may have been a deterrent for any commercial interest in a DNA test for Tay-Sachs. The enzyme test for Tay-Sachs was never patented and therefore patents did not help or hinder its development or commercialization.

The impact that the Canavan patent had on commercialization is unclear. The controversy happened at the level of Miami Children's Hospital, not in litigation among competing commercial testing services. The lawsuit was about fair access and distribution of benefits, not commercialization per se.

\section{Adoption by third-party payers}

Adoption of Tay-Sachs and Canavan disease carrier and prenatal screening by third-party payers is varied. For example, CIGNA covers both carrier and prenatal screening for TaySachs and Canavan if eligibility criteria are met. CIGNA considers carrier testing medically necessary for individuals who have either an affected family member or a reproductive partner with confirmed adult-onset TSD. Prenatal testing or PGD is considered medically necessary if both parents are heterozygous and do not carry a pseudodeficiency allele; one parent is heterozygous and the other parent's test was inconclusive; the mother is heterozygous and the father's status is unobtainable; or one parent has adult-onset TSD. ${ }^{37}$

CIGNA considers carrier testing for Canavan Disease medically necessary when the ASPA mutation has been identified in a family member, and the patient has the capacity and desire to reproduce. Prenatal testing and PGD are considered necessary when both reproductive partners are of Ashkenazi Jewish descent, or when both disease-causing alleles have been identified in an affected family member, and one parent is known to be heterozygous. ${ }^{38}$

Aetna does not have a policy on carrier screening, but considers genetic counseling in connection with pregnancy management medically necessary in specific populations, including people of Ashkenazi Jewish descent. Aetna also considers genetic counseling medically necessary in situations where both parents are known carriers of an autosomal recessive disorder, such as Tay-Sachs or Canavan. ${ }^{39}$ Aetna's policy on genetic testing does not include carrier screening: their policy position only applies to the establishment of a molecular diagnosis of an inheritable disease in an individual. ${ }^{40}$

For other insurance companies that do not cover genetic testing for people of Ashkenazi Jewish descent, the National Tay-Sachs and Allied Diseases organization offers to send help in the form of a letter to the insurer or health plan. ${ }^{35}$ 


\section{REFLECTIONS}

Although the Tay-Sachs and Canavan disease stories have much in common, a few salient differences make a direct comparison difficult. The first such difference is the relative clinical importance of the cloning of the aspartoacylase and hexosaminidase genes. The identification and cloning of the hexosaminidase gene by Dr. Rachel Myerowitz was a scientific and intellectual triumph; the cloning of the aspartoacylase gene by Dr. Reuben Matalon was a medical necessity for a community with very few options. Perhaps Dr. Myerowitz herself put it best:

\begin{abstract}
.. Finding out the mutations [for the $H E X$ genes] was fine ... but they have a very fine enzymatic screen which is really far superior, and the reason it's superior is because it's an all-encompassing screen. If you have individual mutation screens, they're okay for ethnic groups, but what if there's an Ashkenazi Jew who has a new mutation, or his mother wasn't really Jewish? You would miss them. So really, my discovery of the mutations was intellectually interesting, but it wasn't like you had a community waiting for prenatal testing like I believe you did in Canavan. (R. Myerowitz, personal communication, 2007)
\end{abstract}

Dr. Myerowitz's modesty understates the importance of TaySachs DNA tests in specific ethnic groups, especially the Ashkenazim. The DNA test for Tay-Sachs also has clinical utility: it is useful for determining the specific mutations in an individual, for confirming an inconclusive enzyme test, for identifying pseudodeficiency alleles, and for PGD. It is nonetheless true that DNA testing is much more clinically pervasive for Canavan disease than Tay-Sachs.

Another salient difference is patent status. Both genes were patented, but no attempt was made to commercialize a test based on the Tay-Sachs gene, and that patent was never licensed; in contrast, the Canavan gene was licensed with a relatively high royalty and with volume restrictions. One reason that the TaySachs patent was never licensed is that there was already a working enzyme assay, which may have decreased commercial interest in licensing the DNA-based patent. Because the assay was already available, there would likely not be a market for an expensive DNA test. With Canavan's, in contrast, the market was open for prenatal screening based on a DNA test, and so the gene patent was more commercially significant.

One interesting fact that has come to light as a result of this study is that the availability and pricing of Tay-Sachs and Canavan Disease screening and DNA testing is similar, despite the difference in the intellectual property scenarios. This may indicate that using such a metric to compare patient access is inaccurate, although this seems unlikely given the similar population and screening scenarios for both conditions. It may also indicate a reduction in royalties as a part of the 2003 settlement of Greenberg $v \mathrm{MCH}$

$\mathrm{Had} \mathrm{MCH}$ been able to enact the licensing terms they originally intended to pursue - a $\$ 25$ or $\$ 50$ royalty, volume limitations, a single high-volume provider, and refusing to name licensed laboratories - it may well have created an access problem for the Canavan community. This case highlights an instance in which members of a community and clinical providers serving that community took legal actions because of their concern over an access problem. The legal actions they pursued may have played a role in mitigating the long-term access problem that might have resulted from the MCH's original licensing scheme.

\section{WHAT HAS THIS GOT TO DO WITH PATENTS?}

Patents are only a part of any story of health care innovation. This story clearly shows how patent policy is only one feature of a complex set of policies that influence innovation in health care, including introduction of a new genetic screening and testing procedure.

One solution is to eliminate DNA sequence patents, along the lines of the Becerra-Weldon bill (HR 110-997). Without patents, the licensing controversy would not have been possible, so patents are part of the story. The implication that eliminating gene patents would resolve all issues, however, introduces other possible consequences. At the time it was discovered, the Canavan gene was considered a possible target for gene therapy; or the gene patent might have been important in producing aspartoacylase protein for therapeutic use, along the lines of treatment for Gaucher disease, adenosine deaminase deficiency, or other enzyme deficiencies. The absence of a gene patent could have made inducing investment in the therapeutic developments difficult, a socially suboptimal outcome. Such treatments have not developed for Canavan disease, but patents on genes for other therapeutic proteins have proven important in the past and might do so in the future. So the policy option of eliminating DNA sequence patents, while avoiding Canavan-like controversies, also comes with a price.

The main lesson of the Canavan case is that exclusive property rights can be used unwisely. Without the property right, the problems do go away, but so also do any benefits of intellectual property. The Canavan case could easily have been a story similar to cystic fibrosis or Huntington disease, in which the constituencies that were involved in the discovery were at the table when decisions were made about patenting and licensing. The narrative in those cases is one of scientific success leading to broad availability not only of a genetic test but also creating new pathways for scientific advance building on the discovery of mutations in a causative gene. Patents were also part of those stories, but patenting did not cause a shift in the cystic fibrosis or Huntington narrative from heroic scientific discovery to secrecy, betrayal, and greed - the way the Canavan story played out in the public media. The difference was partly about licensing strategy, but more importantly, it was about human and organizational relationships.

One of the emerging frameworks for technology licensing is to see it more as a tool for building a collaborative framework to build relationships and foster innovation and less as a legalistic entitlement to be used as a weapon to extract revenue and overcome opposition. ${ }^{41} \mathrm{MCH}$ 's patenting and licensing mistakes included failure to inform groups involved in the initial discovery about the decision to apply for a patent and then deciding to engage the organizations that had existing systems of testing Ashkenazi Jewish populations through legalistic "cease and desist" letters rather than involving them early and having them at the table when initial licensing decisions were being made. This is, again, a stark contrast with the much more successful introduction of genetic testing for Huntington disease or cystic fibrosis, where analogous constituencies were involved early and directly as partners, rather than late and through legalistic tactics as adversaries.

The main conclusion from this case study is that patents matter, but they are tools, not ends in themselves. How they are used matters as much or more than whether they exist at all. The story is both a travesty of poor management of intellectual property and a story of tort law and litigation leading to a settlement acceptable to the parties. If managed sensibly, and with involvement of stakeholders, patented technologies can generate revenues for research institutions without hindering research or clinical use and (at least in this case) ultimately with few discernible impacts on prices of or access to genetic testing. 
If mismanaged, patent licensing can cause controversy, disrupt systems of genetic testing and screening, and damage the reputations of scientists and research institutions.

\section{ACKNOWLEDGMENTS}

The case study authors have no consultancies, stock ownership, grants, or equity interests that would create financial conflicts of interest. The Center for Genome Ethics, Law \& Policy accepts no industry funding. Dr. Robert Cook-Deegan is listed on the British Medical Journal roster of physicians who have pledged to remain independent of industry funding (http:// www.tseed.com/pdfs/bmj.pdf); more details about how the case studies were done are noted in a July 29, 2009 letter to the Secretary's Advisory Committee on Genetics, Health, and Society (http://www.genome.duke.edu/centers/gelp/documents/ SACGHSResponsetopubliccomments.pdf).

All interviews were conducted under Duke University IRB-approved protocol 1277 and usually conducted by phone and recorded. Researchers obtained informed consent from subjects. These interviews are covered by a federal certificate of confidentiality.

This case study was carried out under Grant P50 003391, co-funded by the National Human Genome Research Institute and US Department of Energy, and supplemented by funding from The Duke Endowment.

Daniel and Debbie Greenberg, Orren Alperstein, Rachel Myerowitz, Michael Hopkins, and Michael Watson reviewed this case study to support the work of the Secretary's Advisory Committee.

\section{REFERENCES}

1. Kaback M. Hexosaminidase A deficiency. Available at: http://www. genetests.org $/$ servlet $/$ access $? \mathrm{db}=$ geneclinics \&site $=$ gt\&id $=8888891 \&$ $\mathrm{key}=\mathrm{aMeTZgBKBQ} \mathrm{cB} 9 \& \mathrm{gry}=\& \mathrm{fcn}=\mathrm{y} \& \mathrm{fw}=\mathrm{mD} 3 \mathrm{~m} \&$ filename $=/$ profiles/tay-sachs/index.html. Accessed February 22, 2008.

2. Matalon R, Michals K, Kaul R. Canavan disease: from spongy degeneration to molecular analysis. J Pediatr 1995;127:511-517.

3. Matalon R, Bhatia G. Canavan disease. Available at: http://www.ncbi.nlm.nih.gov/ bookshelf/br.fcgi?book= gene\&part= canavan. Accessed February 22, 2008

4. Monaghan K, Feldman G, Palomaki G, et al. Technical standards and guidelines for reproductive screening in the Ashkenazi Jewish population. Genet Med 2008;10:57-72.

5. Ross L. Heterozygote carrier testing in high schools abroad: what are the lessons for the U.S.? J Law Med Ethics 2006;34:753-764.

6. Kaback M, Desnick R. Tay-Sachs disease: from clinical description to molecular defect. Adv Genet 2001;44:1-9.

7. Kaback M. Screening and prevention in Tay-Sachs disease: origins, update, and impact. Adv Genet 2001;44:253-265.

8. Wailoo K, Pemberton S. The troubled dream of genetic medicine: ethnicity and innovation in Tay-Sachs, cystic fibrosis, and sickle cell disease. In: Eradicating a 'Jewish Gene': promise and pitfalls in the fight against TaySachs disease. Baltimore: Johns Hopkins University Press, 2006:14-61.

9. Clarke L. Mucopolysaccharidosis type I. Available at: http://www.ncbi.nlm.nih. gov/bookshelf/br.fcgi?book= gene\&part =mps1. Accessed February 22, 2008 .

10. Myerowitz R, Proia R. cDNA clone for the alpha-chain of human betahexosaminidase: deficiency of alpha-chain mRNA in Ashkenazi Tay-Sachs fibroblasts. Proc Natl Acad Sci USA 1984;81:5394-5398.

11. Hahn L. Owning a piece of Jonathan. Chicago Magazine. May 2003:83-87, 104-106.

12. Matalon R, Michals K, Sebasta D, Deanching M, Gashkoff PC, Casanova J. Aspartoacylase deficiency and $N$-acetylaspartic aciduria in patients with Canavan disease. Am J Med Genet 1988;29:463-471.

13. Matalon R, Michals K, Gashkoff P, Kaul R. Prenatal diagnosis of Canavan disease. J Inherit Metab Dis 1992;15:392-394.

14. Winerip M. Fighting for Jacob. New York Times Magazine, December 6, 1998:56-63, 78-82, 112 .

15. Matalon R, Kaul R, Gao G, et al. Prenatal diagnosis for Canavan disease: the use of DNA markers. J Inherit Metab Dis 1995;18:215-217.

16. American College of Obstetricians and Gynecologists Committee on Genetics. Committee opinion number 212: screening for Canavan disease. Int $J$ Gynaecol Obstet. 1998;65:91-92.

17. Bennett M, Gibson K, Sherwood W. Reliable prenatal diagnosis of Canavan disease (aspartoacylase deficiency): comparison of enzymatic and metabolite analysis. J Inherit Metab Dis 1993;16:831-836.
18. Besley GT, Elpeleg ON, Shaag A, Manning NJ, Jakobs C, Walter JH Prenatal diagnosis of Canavan disease-problems and dilemmas. J Inherit Metab Dis. 1999;22:263-266.

19. National Tay-Sachs and Allied Diseases Association Inc. What is Canavan disease? Available at: http://www.ntsad.org/. Accessed February 26, 2008.

20. Kaul R, Gao G, Balamurugan K, Matalon R. Cloning of the human aspartoacylase cDNA and a common missense mutation in Canavan disease. Nat Genet 1993;5:118-123.

21. Leonard D. Patents and licensing fundamentals and the nature of the access problem. Secretary's Advisory Committee on Genetics, Health, and Society. Available at: http://oba.od.nih.gov/oba/SACGHS/meetings/June2006/ Leonard3.pdf. Accessed January 14, 2009.

22. Merz J. Discoveries: are there limits on what may be patented? In: Magnus D, Caplan A, McGee G, editors. Who owns life? Amherst, NY: Prometheus Press, 2002:99-116.

23. Greenberg v. Miami Children's Hospital Research Institute, Inc., 264 F. Supp. 2d 1064 (S. D. Fla. 2003)

24. Canavan Foundation Press Release. Available at: http://canavanfoundation. org/news/09-03 miami.php. Accessed February 26, 2008.

25. Cho M, Illangasekare S, Weaver M, Leonard D, Merz J. Effects of patents and licenses on provision of clinical genetic testing services. J Mol Diagn 2003;5:3-8.

26. National Tay-Sachs and Allied Diseases Association of Delaware Valley. Testing information. Available at: http://www.tay-sachs.org/centers.php. Accessed February 26, 2008

27. Student NewsLink. Available at: http://www.news.wisc.edu/newslink/17Nov-2004. Accessed November 17, 2004

28. Santa Monica College. Focus on innovation. Available at: http://www.smc. edu/schedules/archives/profiles/2003/031/coverstories_031.htm. Accessed February 26, 2008

29. Senkevich K. Free Tay-Sachs screening offered on campus. California Aggie. January 27, 2005

30. Ruf S. Center to offer free Tay-Sachs screening. Spartan Daily, November 13, 2001.

31. American College of Obstetricians and Gynecologists Committee on Genetics. Committee opinion number 318: screening for Tay-Sachs disease. $\mathrm{Ob}$ stet Gynecol. 2005;106:893-894.

32. American College of Medical Genetics. Position statement on carrier testing for Canavan disease. Available at: http://www.acmg.net/StaticContent/ StaticPages/Canavan.pdf. Accessed February 26, 2008.

33. American College of Obstetricians and Gynecologists. Committee opinion 298 : prenatal and preconceptional carrier screening for genetic diseases in individuals of Eastern European Jewish descent. Obstet Gynecol. 2004;104:425-428.

34. Bach G, Tomczak J, Risch N, Ekstein J. Tay-Sachs screening in the Jewish Ashkenazi population: DNA testing is the preferred procedure. Am J Med Genet 2001;99:70-75.

35. National Tay-Sachs and Allied Diseases Association I. Insurance coverage. Available at: http://www.ntsad.org/S06/S06inscoverage.htm. Accessed November 5, 2008

36. Flap erupting over royalty for Canavan: Miami Children's Hospital exercises patent for test. Jewish Daily Forward. August 20, 1999:15-16.

37. CIGNA HealthCare. Cigna position statement 0059, genetic testing for Tay-Sachs disease. Available at: http://cigna.com/customer_care/healthcare professional/coverage_positions/medical $/ \mathrm{mm}$ _0059_coveragepositioncriteria_ genetic_testing_for_taysachs_disease.pdf. Accessed February 26, 2008.

38. CIGNA HealthCare. Cigna position statement 0333, genetic testing for Canavan disease. Available at: http://www.cigna.com/customer_ care/healthcare_professional/coverage_positions/medical/mm_0333_ coveragepositioncriteria genetic testing for canavan disease.pdf. Accessed February 26, 2008.

39. Aetna. Aetna clinical policy bulletin: genetic counseling number 0189 . Available at: http://www.aetna.com/cpb/medical/data/100_199/0189.html. Accessed February 26, 2008.

40. Aetna. Aetna clinical policy bulletin: genetic testing number 0140 . Available at: http://www.aetna.com/cpb/medical/data/100_199/0140.html. Accessed February 26, 2008

41. International Expert Group in Biotechnology. Toward a new era of intellectual property: from confrontation to negotiation. Montreal: Innovation Partnership, McGill Centre for Intellectual Property Policy, October 2008.

42. Emory Genetics Laboratory. Tay-Sachs disease: HEXA full gene sequencing test details. Available at: http://genetics.emory.edu/egl/test.php?test_id= 148. Accessed January 21, 2009

43. Emory Genetics Laboratory. Tay-Sachs disease: enzyme assay test details. Available at: http://genetics.emory.edu/egl/test.php?test id=167. Accessed July 24, 2007.

44. Emory Genetics Laboratory. Lysosomal enzyme screening (11 enzyme panel) test details. Available at: http://genetics.emory.edu/egl/test.php?test_ id $=20$. Accessed July 24, 2007.

45. Kennedy Krieger Institute Biochem Genet Laboratory. Test requisition form. Available at: http://www.genetics.kennedykrieger.org/forms/cmsform.pdf. Accessed July 24, 2007. 


\section{APPENDIX: TIMELINE OF KEY DEVELOPMENTS IN TAY-SACHS AND CANAVAN DISEASES}

\section{Patents and Licensing Events}

1997 - US Patent 5,679,635 issues, claiming methods of screening for Canavan disease

1998 - 1999 - Miami Children's Hospital $(\mathrm{MCH})$ sends enforcement letters to hospitals and laboratories testing for Canavan disease

January 20, 2000 - Canavan Disease Screening Consortium and Canavan disease experts meet with $\mathrm{MCH}$ to discuss licensing patents

October 2000 - After MCH fails to find single, large-volume licensee for Canavan testing and only discloses information about 4 of 12 licensees to Canavan Disease Screening Consortium, patient advocacy groups and families with Canavan disease sue MCH, MCH Research Hospital, and Dr. Reuben Matalon (Greenberg v. Miami Children's Hospital)

August 3, 2003 - Greenberg v. Miami Children's Hospital is settled out of court on confidential terms

\section{Technical and Professional Events}

1971 - Drs. John O'Brien and Shintaro Okada develop first enzyme test for TaySachs disease

1990 - Dr. Matalon publishes details of prenatal enzymatic screening test for Canavan Disease

1993 - Dr. Matalon and others publish sequence of normal and mutated aspartoacylase gene, allowing for DNAbased Canavan testing

1995 - American College of Obstetricians and Gynecologists (ACOG) recommend DNA-based carrier screening for Tay-Sachs disease before pregnancy if both parents of Ashkenazi Jewish, French-Canadian, or Cajun descent

1998 - ACOG recommends DNA-based carrier screening for Canavan disease if both parents are of Ashkenazi-Jewish descent and prenatal, DNA-based diagnostic if both parents are carriers 1998 - American College of Medical Genetics (ACMG) recommends that people of Ashkenazi Jewish descent be offered DNA-based carrier screening for Canavan disease prior to pregnancy and that DNAbased screening for Canavan disease and Tay-Sachs disease be combined because both diseases are common among Ashkenazi Jews 